\title{
Commentary on Bal (2020): Recognizing People at Work in Their Full Humanity
}

\author{
Ulrich Leicht-Deobald \\ University of St.Gallen \\ Institute for Business Ethics \\ Switzerland \\ ulrich.leicht-deobald@unisg.ch
}

Original article: Bal, M. (2020). Why we should stop measuring performance and well-being. German Journal of Work and Organizational Psychology, 64 (3).

https:/doi.org/10.1026/0932-4089/a000333.

Leicht-Deobald, U. (2020). Commentary on Bal (2020): Recognizing people at work in their full humanity. German Journal of Work and Organizational Psychology, 64 (3). https://doi.org/10.1026/0932-4089/a000335. 
To my delight, I read the essay, "Why we should stop measuring performance and well-being" by Matthijs Bal (2020). This work cautions us to consider carefully the outcomes we study in Work and Organizational Psychology (WOP). It offers a stunning critique of the one-sided — and sometimes mindless — application of performance and/or well-being measures in our research. In short, Bal (2020) argues that we should refrain from using a narrow conceptualization of performance and well-being and rather open our perspectives to include broader notions of what is important as organizational outcomes within both our lives and society as a whole. For Bal (2020), such an alternative viewpoint is exemplified in the concept of dignity that he offers as an alternative guiding principle (Bal, 2017). This essay provides a timely and fresh message for professionals in this field.

Bal (2020) states that empirical studies in WOP hardly ever question the normative assumptions underlying the concepts of performance and well-being. As such, the author suggests that performance per se does not have intrinsic value. Accordingly, performance is normally measured in WOP as an external sense of what elements are instrumental to achieve a task. For example, Bal (2020) discusses a bank employee investing his clients' money in tax havens. Upon executing this task, the employee might receive favorable performance evaluations, even though this action might be damaging to society as a whole. Similarly, the author suggests that studies of well-being tend to neglect structural aspects of power and exploitation.

Bal's (2020) article inspired me to ponder whether our struggle to include normative aspects within our theorizing is partly due to this functional/positivist epistemology in WOP. This functional/positivist paradigm has been the dominant logic in WOP regarding what constitutes legitimate knowledge. An important characteristic of this functional/positivist paradigm is that theory can be formulated in mathematical terms; explanations take the form of causal statements or models incorporating variables (Poole, Van de Ven, Dooley, and Holmes, 2000). The functional/positivist epistemology, however, tends to assume that the 
underlying concepts are descriptive, a stance that bears the risk of missing the normative connotation of those concepts (Werhane, 1994). Alternative epistemologies, based on interpretative approaches and process philosophies, such as Pragmatism or Social Constructionism, are more sensitive to normative accounts. As such, those approaches might help scholars in WOP to augment their methodological repertoire. Although I do not see that prior work on job crafting or working meaning has necessarily been agnostic to the normative aspects embedded in such concepts, I do believe similar to Bal (2020), that we should carefully contemplate as scholars the structural aspects of power within the contexts in which we examine and apply our ideas.

Furthermore, Bal (2020) nicely fleshes out the idea that the epistemology of how we study performance and well-being is problematic, as are its corresponding ontological underpinnings. The ontology underlying the functional/positivist paradigm, for example, tends to emphasize instrumentality and objectivity over relationality. Bal (2020) suggests that such an ontology is prone to reducing any living being (such as people, animals, or the natural environment) to the logic of explaining the association between material objects, regardless whether these objects are living beings or mere things. As such, the functional/positivist paradigm teaches us to see what we are as material objects but does not help us see who we are as persons in relation to our living possibility. A fruitful alternative lens offering a different idea of man is Personalism (Melé, 2012), which draws from a wide array of thinkers, such as Thomas Aquinas, Emanuel Levinas, and Martin Buber. It promises to offer a more relationship-oriented ontology than functionalism/positivism to help us understand who we are as humans (Leicht-Deobald, Garrett, \& Sandelands, in press). This perspective stands in stark contrast to the liberal conception of man, which views man predominantly as a rational agent maximizing his self-interest.

One discussion point that stood out for me is that Bal (2020) seems to attribute the narrow conceptualization of performance and well-being in WOP to the neoliberal ideology. I 
agree with Bal (2018) that the cultural movement of neoliberalism gained traction after the end of the Cold War (with historical origins extending further back than the 1990s). Furthermore, I agree that this movement shaped much of the public economic policy discourse during the last 30 years. At the same time, I believe the problem runs deeper theoretically as well; from my perspective, the field of WOP does not offer a working model of a firm that reaches beyond what economists offer us in their theory of the firm (Jensen \& Meckling, 1976). As a matter of principle, this lens prioritizes efficiency (in the form of shareholder value or its many guises) over alternative criteria (such as beauty, righteousness, or goodness). We would be well advised in WOP to develop our own ideas regarding the purpose of a firm.

In summary, I applaud Bal (2020) for offering explicit illumination of some of the problematic assumptions underlying our concepts of performance and well-being. This is a timely wake-up call to reflect upon the alternative outcomes to study and upon the normative epistemological and ontological foundations we apply in our research. At the same time, I believe there is hope exemplified in the emerging initiatives in WOP, such as the Future of Work and Organizational Psychology (Bal et al., 2019), the movements of Positive Organizational Scholarship (Cameron, Dutton, \& Quinn, 2003), or Humanistic Management (Pirson, 2017). These movements have already helped us broaden the scope of legitimate outcomes of study, including notions of dignity (Bal, 2017), compassion (Dutton, Workman, \& Hardin, 2014), or respect (Van Quaquebeke \& Felps, 2018) and how we study those ideas. We are blessed to have a scholar like Bal in our field, inviting us to think differently about the concepts and language we use in our research. 


\section{References}

Bal, M. (2017). Dignity in the workplace: New theoretical perspectives. Palgrave Macmillan: London.

Bal, M. (2020). Why we should stop measuring performance and well-being. German Journal of Work and Organizational Psychology, 64 (3). https:/doi.org/10.1026/09324089/a000333.

Bal, M., \& Dóci, E. (2018). Neoliberal ideology in work and organizational psychology. European Journal of Work and Organizational Psychology, 27, 536-548.

Bal, P.M., Dóci, E., Lub, X., Van Rossenberg, Y. G. T., Nijs, S., Achnak, S., Briner, R. B., Brookes, A., Chudzikowski, K., De Cooman, R., De Gieter, S., De Jong, J., De Jong, S. B., Dorenbosch, L., Ghoreishi Galugahi, M. A., Hack-Polay, D., Hofmans, J., Hornung, S., Khuda, K., Klamer, R., Mendy, J., Mol, S. T., Navarro, J., Notelaers, G., Ossenkop, C., Pickett, J., Röllmann, L., Sanderson, Z., Sosnowska, J., Spanouli, A., Vantilborgh, T., Van Dijk, H. \& Van Zelst, M. (2019). Manifesto for the future of work and organizational psychology. European Journal of Work and Organizational Psychology, 28(3), 289-299.

Cameron, K. S. Dutton, J. E., \& Quinn, R. E. (2003). Positive organizational scholarship: Foundations of a new discipline. San Francisco: Berrett-Koehler.

Dutton, J. E.,Workman K. M., \& Hardin, A. E. (2014).Compassion and work organizations. Annual Review of Organizational Psychology and Organizational Behavior, 1(1), 277 304.

Jensen, M. C., \& Meckling, W. H. (1976). Theory of the firm: Managerial behavior, agency costs and ownership structure. Journal of Financial Economics, 3(4), 305-360.

Leicht-Deobald, U., Garrett, L., \& Sandelands, L. (in press). What it means to be truly human in organizations: Martin Buber idea of I-Thou relations. In D. Korten, M. Pirson, D. Wasieleski, E. Steckler, \& R. Aguado (Eds.), Alternatives to the theory of the firm. London: Routledge Publishers.

Melé, D. (2012). The firm as a "community of persons": A pillar of humanistic business ethos. Journal of Business Ethics, 106(1), 89-101

Pirson, M. (2017). Humanistic management: Protecting dignity and promoting well-being. Cambridge: Cambridge University Press.

Poole, M. S., Van de Ven, A. H., Dooley, K., \& Holmes, M. E. (2000). Organizational change and innovation processes: Theory and methods for research. New York: Oxford University Press.

Quaquebeke, N. V., \& Felps, W. (2018). Respectful inquiry: A motivational account of leading through asking questions and listening. Academy of Management Review, 43(1), $5-27$.

Werhane, P. (1994). The normative/descriptive distinction in methodologies of business ethics. Business Ethics Quarterly, 4(2), 175-180. 